Postprint of Journal of the American Oil Chemists' Society, volume 95, issue11, November 2018, pages 1399-1408

DOI: https://doi.org/10.1002/aocs.12146

\title{
MICROENCAPSULATION OF CONJUGATED LINOLEIC ACID (CLA)-RICH OIL WITH SKIMMED MILK COMPONENTS PROTECTS AGAINST POLYMERIZATION
}

Running title: Microencapsulation of CLA-rich oil

Francisca Holgado', M. Carmen García-Martínez', Joaquín Velasco ${ }^{2}$, M. Victoria Ruiz-Méndez ${ }^{2}$ and Gloria Márquez-Ruiz ${ }^{1^{*}}$

${ }^{1}$ Instituto de Ciencia y Tecnología de Alimentos y Nutrición (ICTAN-CSIC), José Antonio Novais 10, 28040 Madrid, Spain.

${ }^{2}$ Instituto de la Grasa (IG-CSIC), Campus Universidad Pablo de Olavide, Ctra. de Utrera km. 1, 41013 Seville, Spain.

${ }^{*}$ Corresponding author:

Dr. Gloria Márquez-Ruiz, Instituto de Ciencia y Tecnología de Alimentos y Nutrición (ICTAN-CSIC), José Antonio Novais 10, 28040 Madrid, Spain.

Phone: +34915492300, Fax:+34915493627, E-mail: gmarquez@ictan.csic.es

\section{Acknowledgments}


This work was funded by Project AGL 2013-45110-R of the Spanish Ministry of Economy and Competitiveness (MINECO). 


\section{Abstract}

Oils rich in conjugated linoleic acid (CLA) are currently used in functional foods because of the positive health effects of some CLA isomers. In this work, microencapsulation of a CLA-rich oil (containing approx. $80 \%$ of a mixture of $9 c$, $11 t$ and $10 t, 12 c$ - linoleic acid) with skimmed milk components is proposed as a means to protect it from oxidation and polymerization. The main physicochemical characteristics, i.e. glass transition temperature, and mean oil globule size and distribution, were evaluated. Microencapsulated samples, both intact and devoid of free oil fraction, along with the bulk oil, were oxidized at $30^{\circ} \mathrm{C}$ in the dark for 3 months. Throughout storage, free and encapsulated oil fractions were separately extracted from samples and analyses included substrate loss by GLCFID, polymers determination by HPSEC-RID and tocopherol content by HPLCFD. Results showed that free oil oxidized much more rapidly than encapsulated oil. In encapsulated oil fractions, high amounts of polymers accumulated in samples with considerable high levels of tocopherols remaining. In samples devoid of free oil, a drastic change in physical properties occurred but the oil polymerized to a similar extent to that found in the encapsulated fractions of intact samples.

Keywords: Conjugated linoleic acid, CLA, oxidation, microencapsulation, polymerization 


\section{Introduction}

Conjugated linoleic acid (CLA) is a collective term of a group of positional and geometric isomers of linoleic acid formed by rumen bacterial hydrogenation combined with mammalian delta 9-desaturation. The proportion of CLA ranges from $0.12 \%$ to $0.68 \%$ of total fat in beef and from 0.34 to $1.07 \%$ of total fat in milk (Fritsche et al., 1999). The most biologically active isomers of CLA are cis-9, trans-11-linoleic acid (rumenic acid), which is the most abundant isomer in nature, and trans-10, cis-12-linoleic acid (Pariza, Park \& Cook, 2000; Yang et al., 2015). Anticarcinogenic and antiatherogenic effects have been attributed to the cis-9, trans-11 isomer (Ha, Storkson \& Pariza, 1990; Masso-Welch et al., 2004), while the trans-10, cis-12 isomer is claimed to promote weight loss and muscle-mass enhancement (Malpuech-Brugere et al., 2004; Whigham, Watras \& Schoeller, 2007).

Nowadays CLA is used as a functional ingredient, especially in the form of oil (García-Martínez \& Márquez-Ruiz, 2009). Commercial CLA-rich oils are mostly obtained through alkali isomerization of safflower or sunflower oils (Saebo, 2003), and contain approximately $80 \%$ of CLA with almost equal amounts of $9 c, 11 t$ and $10 t$, 12c- linoleic acid, as well as trace amounts of other isomers. One of the most used CLA-rich oil is Tonalin ${ }^{\mathrm{TM}} \mathrm{TG} 80$, constituted by mainly triacylglycerols (approx. 80\%) and diacylglycerols (approx. 20\%). As all polyunsaturated fatty acids, CLA is highly susceptible to oxidation and therefore effective food 
supplementation with CLA should guarantee protection of these bioactive fatty acids. Microencapsulation is a powerful strategy to prepare food ingredients that require protection from oxidation and other chemical deterioration like loss of flavours or vitamins (Shahidi \& Han, 1993; Gharsalloui, Roudart, Chambin, Voilley \& Saurel, 2007; Dias, Ferreira \& Barreiro, 2015), and especially oils rich in long-chain polyunsaturated fatty acids (Márquez-Ruiz, Velasco \& Dobarganes, 2003; Drusch \& Mannino, 2009; Bakry et al., 2016). Hence it has been also proposed to enhance oxidative stability of CLA in a few studies (Kim et al., 2000; Jiménez, García \& Beristain, 2004, 2006; Lee et al., 2009; Choi, Ryu, Kwak \& Ko, 2010; Costa et al., 2015).

In such studies, the acid form of CLA was the only compound used and the only or main objective was to test different matrix components and analyze encapsulation efficiency and physico-chemical properties. With the exception of Kim and coworkers (Kim et al., 2000), who used headspace-oxygen depletion to compare different cyclodextrins as encapsulating agents, and Jiménez and coworkers when compared losses of CLA during storage at different relative water activities (Jiménez, García \& Beristain, 2004), only peroxide value was used as oxidation measurement and a range of very low values was generally reported. Besides and unfortunately, the free and the encapsulated fractions of microencapsulated CLA throughout oxidation were not analyzed separately in neither of these studies, which is essential because of the heterogeneous oxidation rates observed in these complex, discontinuous systems (Velasco, 
Marmesat, Dobarganes \& Márquez-Ruiz, 2006, 2009; Morales, Marmesat, RuizMéndez, Márquez-Ruiz \& Velasco, 2015).

The mechanism of oxidation of conjugated systems is unclear and different pathways to those established for major, non-conjugated fatty acids seem to be involved (Yurawecz, Delmonte, Vogel \& Kramer, 2003; Brimberg \& Kamal-Eldin, 2003). In previous works, we demonstrated that peroxide value or any other determination measuring hydroperoxides is not indicative of the oxidation state of CLA substrates since polymer formation is otherwise the earliest and predominant event on the CLA oxidation progress (Luna, De la Fuente, Salvador \& Márquez-Ruiz, 2007; García-Martínez, Márquez-Ruiz, Fontecha \& Gordon, 2009; Márquez-Ruiz, García-Martínez, Holgado \& Velasco, 2014; Márquez-Ruiz, Holgado, Ruiz-Méndez, Velasco \& García-Martínez, 2016). Furthermore, we found that heptanal and trans-2-nonenal were volatile compounds exclusively formed from CLA (García-Martínez, Márquez-Ruiz, Fontecha \& Gordon, 2009; Márquez-Ruiz, Holgado, Ruiz-Méndez, Velasco \& García-Martínez, 2016).

The objective of this work was to study the oxidative behavior of a CLA-rich oil (Tonalin $^{\mathrm{TM}}$ TG 80 oil) microencapsulated in skimmed milk components for the first time through separation of free and encapsulated oil fractions and using the determination of polymerization compounds as the most valid method to evaluate oxidation in CLA substrates. 


\section{Materials and Methods}

\section{Materials}

Tonalin $^{\text {TM }}$ TG 80 oil (TO) was acquired from Cognis Nutrition and Health (Cincinnati, OH, USA). Two batches of microencapsulated Tonalin ${ }^{\mathrm{TM}}$ oil samples (MT) were supplied by a local dairy-manufacturer and elaborated with the same preparation conditions that consisted in addition of TO to skimmed milk $(1 \% \mathrm{w} / \mathrm{v})$, two passes at $20 \mathrm{MPa}$ for their homogenization $(20,000 \pm 1,000 \mathrm{kPa})$, sterilization through with $\mathrm{UHT}$ indirect process $\left(142^{\circ} \mathrm{C}\right.$ for 6 seconds), evaporation under vacuum (temperature below $72^{\circ} \mathrm{C}$ ) and spray-drying by atomization (air inlet temperature: $185^{\circ} \mathrm{C}$, air outlet temperature: $90^{\circ} \mathrm{C}$ ). The dried product contained theoretically $10 \%$ oil (minimum $6 \%$ TO), $36 \%$ proteins $(29.5 \%$ caseins and $6.5 \%$ whey proteins) and $54 \%$ lactose. Tocopherol standards ( $\alpha-, \gamma-$ and $\delta$-) (purity $>99 \%$ ) were purchased from Sigma Chemical Co. (St. Louis, MO). All the other chemicals used were of analytical grade and obtained from local suppliers.

\section{Oxidation conditions}

MT and TO samples were stored under non-limited oxygen conditions in a desiccator containing silica gel, at $30{ }^{\circ} \mathrm{C}$ in the dark. 


\section{Lipid extractions}

Total oil

The procedure applied was based on the Rose-Gottlieb method (Richardson, 1985), widely accepted for quantitative determination of fat in milk and milk powders. Briefly, $4 \mathrm{~g}$ of MT was dispersed in $40 \mathrm{~mL}$ of water heated at $65^{\circ} \mathrm{C}$ in a 250-mL flask. A volume of $8 \mathrm{~mL}$ of $30 \% \mathrm{NH}_{4} \mathrm{OH}$ was added, the solution was gently stirred, the flask was closed and heated at $65^{\circ} \mathrm{C}$ for $15 \mathrm{~min}$ in a shaking water bath. Then, the solution was cooled at room temperature and the oil was extracted by applying three liquid-liquid extractions as follows: first, $20 \mathrm{~mL}$ ethanol, $50 \mathrm{~mL}$ diethyl ether and $50 \mathrm{~mL}$ hexane; second, $10 \mathrm{~mL}$ ethanol, $50 \mathrm{~mL}$ diethyl ether and $50 \mathrm{~mL}$ hexane; and third, $50 \mathrm{~mL}$ diethyl ether and $50 \mathrm{~mL}$ hexane. The components in each mixture of solvents were added separately and gentle shaking was applied after each addition. The organic phase was filtered through a filter paper containing anhydrous $\mathrm{Na}_{2} \mathrm{SO}_{4}$ and then the solvent was evaporated in a rotary evaporator at $40{ }^{\circ} \mathrm{C}$. The extracted oil was finally dried to constant weight using a stream of nitrogen.

Free oil

The free oil fraction was extracted according to Sankarikutty and coworkers (Sankarikutty, Sreekumar, Narayanan \& Mathew, 1988). A volume of $200 \mathrm{~mL}$ of 
$\mathrm{n}$-hexane was added to $10 \mathrm{~g}$ of MT. Then, stirring was applied for $15 \mathrm{~min}$ at room temperature. After filtration through a filter paper, the solvent was evaporated in a rotary evaporator and the extracted oil was dried to constant weight by using a stream of nitrogen.

\section{Encapsulated oil}

Partial extraction of encapsulated oil consisted of disruption of the solid matrix with a mortar and pestle and subsequent extraction of the lipids released with hexane. A $3 \mathrm{~mL}$ volume of water was added to $10 \mathrm{~g}$ of MT and the mixture was rubbed with a mortar and pestle until a dough was made. Then, $5 \mathrm{~g}$ of anhydrous $\mathrm{Na}_{2} \mathrm{SO}_{4}$ were added and mixed with the mortar and pestle to retain the water. The lipids were obtained by 3 extractions with $70 \mathrm{~mL}$ of hexane. After filtration through a filter paper the solvent was evaporated at $40{ }^{\circ} \mathrm{C}$ in a rotary evaporator. Remaining solvent was removed from the extracted lipids with a stream of nitrogen at room temperature (Velasco, Marmesat, Dobarganes \& Márquez-Ruiz, 2006).

\section{Physicochemical properties}

Microencapsulation efficiency (ME) 
Microencapsulation efficiency was determined from the quantitative extraction procedures described earlier for the total and the free oil fractions as follows:

$$
\operatorname{ME}(\%)=\frac{(\text { Total oil }- \text { Free oil })}{\text { Total oil }} \times 100
$$

\section{Oil droplet size}

Analysis of oil droplet size was performed in the powders reconstituted in water at a weight ratio of $1: 7$. The emulsions were readily reconstituted by dispersing the dried samples in deionised water at room temperature and applying vigorous shaking. A Malvern Mastersizer X (Malvern Instruments, Malvern, UK) operating with a $2 \mathrm{~mW}$ He-Ne laser beam $(\lambda=633 \mathrm{~nm}$ ) and a $45 \mathrm{~mm}$ lens (size range $0.05-80 \mu \mathrm{m})$ was used. A relative refractive index $\eta_{\text {oil }} / \eta_{\text {water }}=1.095$ and an absorption value of 0.1 were used in the calculations (Holgado, Márquez-Ruiz, Dobarganes \& Velasco, 2013).

Water activity

The water activity of the microencapsulated was measured using a Pawkit hygrometer (Decagon Devices Inc., Pullman, WA, USA). 
The glass transition temperature (Tg) was determined using a DSC Q 2000 calorimeter (TA Instruments, New Castle, DE, USA). Calibration of heat flow and temperature was performed with indium as standard $\left(\mathrm{mp}=156.6^{\circ} \mathrm{C}, \Delta \mathrm{H}_{\text {fus }}=\right.$ $\left.28.5 \mathrm{~J} \mathrm{~g}^{-1}\right)$. An aliquot of $10 \mathrm{mg} \mathrm{MT}$ was hermetically sealed into a $40 \mu \mathrm{L}$ aluminum DSC crucible. An empty sealed aluminum crucible was used as reference. Heating runs at a rate of $10{ }^{\circ} \mathrm{C} \mathrm{min}^{-1}$ were used from 0 to $125{ }^{\circ} \mathrm{C}$. Duplicates and rescans were performed in each case to make sure that endothermic changes of the baseline corresponded to the $\mathrm{Tg}$. The $\mathrm{Tg}$ was determined by the automatic mode of Universal Analysis 2000 (TA Instruments), that is, the inflection point of the endothermic baseline shift.

\section{Color measurements}

Color data were measured in the $\operatorname{CIE} 1976\left(\mathrm{~L}^{*}, \mathrm{a}^{*}, \mathrm{~b}^{*}\right)$ colour space by using a CM-3500d Konica Minolta colorimeter in a $400-780 \mathrm{~nm}$ range.

Time for powder reconstitution in water and $\mathrm{pH}$

The time for powder reconstitution in water was measured at $26^{\circ} \mathrm{C}$ using $2 \mathrm{~g}$ of sample and $50 \mathrm{~mL}$ deionised water. Stirring at $300 \mathrm{rpm}$ was applied and the time required for a complete dissolution was determined (Jiménez, García \& Beristain, 2010). Afterwards, the $\mathrm{pH}$ of the corresponding reconstituted emulsions was measured. 


\section{Fatty acid composition}

Fatty acid composition was determined in TO and in the extracted oil fractions from MT samples. Previous derivatization to FAMEs with $2 \mathrm{M} \mathrm{KOH}$ in methanol, FAMEs were analyzed by GC- 6850 (Agilent Technologies, Palo Alto, CA, USA) equipped with a FID detector. FAMEs $(\mathrm{c}=50 \mathrm{mg} / \mathrm{mL}$ in hexane, volume injected $=2 \mu \mathrm{L})$ were separated using HP Innowax capillary column $(30 \mathrm{~m} \times 0.25$ $\mathrm{mm}$ id, $0.25 \mu \mathrm{m}$ film thickness). The temperature program used was $180^{\circ} \mathrm{C}$ for 2 $\mathrm{min}$, followed by $3^{\circ} \mathrm{C} / \mathrm{min}$ increase to $230^{\circ} \mathrm{C}$ and held there for $20 \mathrm{~min}$. The temperatures of the injector and detector were held at $250^{\circ} \mathrm{C}$. Hydrogen was the carrier gas at a flow rate of $1 \mathrm{~mL} / \mathrm{min}$ with a split ratio of 1:40 (IUPAC, 1992a, 1992b).

\section{Determination of dimers and polymers}

Polymerization compounds were determined following the IUPAC standard method (IUPAC, 1992c). TO and extracted oil fractions from MT were dissolved in THF $(50 \mathrm{mg} / \mathrm{mL})$ and analyzed in an HPSEC chromatograph equipped with a Rheodyne $7725 \mathrm{i}$ injector with $10-\mu \mathrm{L}$ sample loop, a Knauer 1200 HPLC pump (Knauer, Germany) and a Waters 2414 refractive index detector (Waters, Milford,

MA, USA). The separation was performed on two $100-$ and $500-\AA$ Ultrastyragel columns ( $25 \mathrm{~cm} \times 0.77 \mathrm{~cm}$ i.d., $10 \mu \mathrm{m}$ film thickness) packed with porous, highly 
cross-linked styrene-divinylbenzene copolymers (Agilent Technologies, Palo Alto, CA, USA) connected in series, with tetrahydrofuran $(1 \mathrm{~mL} / \mathrm{min})$ as the mobile phase. The peaks resolved by HPSEC corresponding to polymerization compounds were triacylglycerol polymers $(P)$ and triacylglycerol dimers $(D)$.

\section{Determination of tocopherols}

Analysis of tocopherols was performed by normal-phase HPLC with fluorescence detection according to IUPAC Standard Method (IUPAC, 1992d).

\section{Determination of peroxide value}

Peroxide value (PV) was determined by the standard iodometric method, according to the (AOCS, 1998). Samples of $100 \mathrm{mg}$ of oil and a $0.01 \mathrm{~mol} / \mathrm{L}$ $\mathrm{Na}_{2} \mathrm{~S}_{2} \mathrm{O}_{3}$ solution were used.

\section{Determination of the Oxidative Stability Index (OSI)}

OSI was determined in a 743 Rancimat device (Metrohm, Switzerland). Samples of bulk oil (2.5 g $\pm 0.1 \mathrm{~g}$ ) were placed into Rancimat standard tubes and subjected to the normal operation of the test by heating at $100{ }^{\circ} \mathrm{C}$ with a flow of air of $20 \mathrm{~L} / \mathrm{h}$. Evaluation mode 1 provided by the test as the intersection point of the two extrapolated straight parts of the conductivity curve was taken as the OSI. 


\section{Statistical Analysis}

Characterization data were obtained by using three determinations. The oxidation experiments were carried out in triplicate and results for polymerization compounds and tocopherols were expressed as mean values. Comparisons between means were made by applying one-way ANOVA using SPSS Statistics version 17.0 (SPSS Inc., Ireland). Differences between means were determined using Tukey's test. Significant differences were established at $p<0.05$.

\section{Results and discussion}

\section{Characterization of oil and microencapsulated oils}

Table 1 shows fatty acid and tocopherol compositions, and oxidative parameters of the TO used to prepare the MT samples. As can be observed, content of main isomers of CLA, $9 c, 11 t$ and $10 t, 12 c$ were very similar and sum up almost $80 \%$. Level of total tocopherols was $732 \mathrm{mg} / \mathrm{kg}$ being $\gamma$ - tocopherol the most abundant. The PV and initial polymer content were low and typical of fresh refined oils.

Tables 2 shows main physicochemical characteristics and Table 3 shows fatty acid and tocopherol compositions, and oxidative parameters, of initial samples of MT1 and MT2 batches and MT devoid of free oil fraction (MT2b). Figure 1 shows the oil size distribution profiles and DSC thermograms of MT1, MT2 and MT2b. 
Oil content was similar in both batches (about 8\%) and high encapsulation efficiencies were obtained, although significantly higher for MT2. Oil droplet size characteristics were similar for all samples. Values of Tg for MT1 and MT2 were, as expected, close to that of the carbohydrate contained in the skimmed milk, i.e., lactose (Thomas, Scher \& Desobry-Banon, 2004). However, after removal of the free oil fraction of MT2, it was noted that a drastic drop of $\mathrm{Tg}$ occurred and oil globule dispersion decreased, attributable to structural changes in the matrix during washing with hexane and re-drying. However, oil globule size parameters and $a_{w}$ were similar for MT2 and MT2b, and solubility was only slightly slower in MT2b, even though some authors believe the opposite is likely to occur since oil in the surface of particles may partly impede the contact between matrix and water (McNamee, O’Riordan \& O'Sullivan, 1998).

Fatty acid composition of MT1, MT2 and MT2b (Table 3) showed marked differences with respect to TO (Table 1), specifically the CLA isomers proportion was significantly lower in microencapsulated oil samples while, conversely, contents of $\mathrm{C} 16: 0$ and C18:0 were significant higher. Also, short- and mediumchain fatty acids were detected in MT samples, attributable to the residual milk fat present in skimmed milk, as already reported (Rodríguez-Alcalá \& Fontecha, 2007). Also, it was clear that MT1 samples contained more milk fat, as reflected in slightly higher contents of C16:0 and C18:0 and lower contents of CLA isomers. Total tocopherols contents were lower in general in microencapsulated oil samples than in TO and decreased levels were detected in the free compared to 
the encapsulated oil fractions in both MT1 and MT2. Moreover, MT2b presented even lower tocopherol content than the encapsulated oil of MT2, and this loss was probably due to the further sample manipulation, i.e. washing with solvent and re-drying.

\section{Polymerization in microencapsulated oils}

Figure 2 shows results obtained throughout storage of all samples at $30^{\circ} \mathrm{C}$, including bulk TO. Results of MT1 and MT2 showed similarly that free oil oxidized much more rapidly than encapsulated oil, as occurred in the case of TO. In free oil fractions of MT samples and TO, polymerization began very soon while in encapsulated fractions only after 40-50 days significant levels of dimers and

polymers were formed. Therefore, the protection exerted by the skimmed-milkcomponents matrix against oxidation of the oil embedded or encapsulated was relevant. Dairy-like matrices have been previosly reported to effectively protect lipids prone to oxidation, such as fish oils (Keogh et al., 2001; Velasco, Dobarganes \& Márquez-Ruiz, 2000; Velasco, Marmesat, Dobarganes \& Márquez-Ruiz, 2006), and caseins seem to contribute greatly to such a protective effect (Drusch, Serfert, Scampicchio, Schmidt-Hansberg \& Schwarz, 2007). In the present work, results showed that, when the antioxidants were exhausted, contents of dimers and polymers were already high but quite different between the free oil fractions (about 5\%) and the encapsulated fractions (about 8-10\%). In other words, in encapsulated oil fractions, high amounts of polymers accumulated in samples with considerably high levels of tocopherols remaining. 
The only difference observed in the oxidative pattern of MT1 and MT2 was the oxidation rate of the encapsulated oil fraction, higher for the former. Thus, MT 1 was totally depleted of tocopherols and had $10 \%$ dimers and polymers after 80 days of storage while MT2 at 77 days kept half the tocopherol content and showed only $2.2 \%$ dimers plus polymers. Differences between oxidative stability of MT1 and MT2 were not attributable to any of the physicochemical properties or oxidative parameters analyzed in the starting samples (Tables 2 and 3), and reflected the influence of other variables involved in the preparation process.

When samples were devoid of free oil (MT2b), polymerization occurred to a similar extent to that found in the encapsulated fractions of intact samples. However, loss of tocopherols in MT2b was comparatively retarded from 65 days of storage, which may be attributed to increased protection of the encapsulated oil fraction following washing with hexane and re-drying because of structural changes that resulted in lower oxygen permeability.

From the data shown in Figure 2, the estimated rate constants for tocopherol loss obtained were much higher in free oil fractions $\left(10.4 \times 10^{4}\right.$ days $^{-1}$ and $13.6 \times 10^{4}$ days $^{-1}$ for MT1 and MT2, respectively) than in encapsulated oil fractions $(0.25 \mathrm{x}$ $10^{4}$ days $^{-1}$ and $0.16 \times 10^{4}$ days $^{-1}$ for MT1 and MT2, respectively). Furthermore and most relevant were the differences found in remnant tocopherols-topolymerization compounds ratio between free and encapsulated oil fractions of MT1 and MT2, as illustrated in Figure 3. Clearly, the proportion of polymerization 
compounds formed in relation with tocopherols levels during the induction period were much higher in encapsulated than in free oil fractions. These results are attributed to the discontinuous oxidation of encapsulated oil, i.e., the coexistence of oil globules at different oxidation extent (from oil globules slightly oxidized with high contents of antioxidants to others highly polymerized and lacking of antioxidants) (Velasco, Marmesat, Dobarganes \& Márquez-Ruiz, 2006, 2009; Morales, Marmesat, Ruiz-Méndez, Márquez-Ruiz \& Velasco, 2015).

To our knowledge, only five studies have been published on oxidation of microencapsulated CLA (Kim et al., 2000; Jiménez, García \& Beristain, 2004, 2006; Lee et al., 2009; Costa et al., 2015).

In all these studies, as commented in the Introduction, the acid form of CLA was used and separate analysis of the free and the encapsulated fraction of microencapsulated CLA throughout oxidation was not carried out. Analysis of oxidation was normally approached by peroxide value measurement and substrate loss determination.

As to peroxide value, results obtained in our lab on CLA model systems and CLA-rich oils have demonstrated that polymer formation and not hydroperoxide formation occurs in CLA systems from the beginning of the oxidation process (Luna, De la Fuente, Salvador \& Márquez-Ruiz, 2007; García-Martínez, Márquez-Ruiz, Fontecha \& Gordon, 2009; Márquez-Ruiz, García-Martínez, Holgado \& Velasco, 2014; Márquez-Ruiz, Holgado, Ruiz-Méndez, Velasco \& 
García-Martínez, 2016). This finding was opposite to what was expected and found in non-conjugated systems thus invalidating peroxide value to control oxidation in CLA systems. In fact, peroxide values obtained by Jiménez and coworkers in microencapsulated CLA during storage were very low (Jiménez, García \& Beristain, 2004, 2006) and even though authors did not discuss these results, they clearly indicated that hydroperoxide formation was minor and not representative of the oxidation state. For example, they reported that samples of CLA microencapsulated in whey proteins stored at 35 and $45^{\circ} \mathrm{C}$ showed CLA losses above $50 \%$ and peroxide values lower than 5 meq $\mathrm{O}_{2} / \mathrm{kg}$ (Jiménez, García \& Beristain, 2004). In a recent publication on CLA oils, we proposed a pathway which can account for the low hydroperoxide amounts formed during oxidation of CLA substrates is the preferential addition of the peroxyl radicals formed during the propagation step to the conjugated diene systems thus leading to peroxyl radical dimers ultimately yielding polymeric peroxides (Márquez-Ruiz, Holgado, Ruiz-Méndez, Velasco \& García-Martínez, 2016). Such polymers cannot be therefore considered termination products characteristic of advanced oxidation stages but primary oxidation compounds formed during the propagation state.

With respect to substrate loss determination by gas-liquid chromatography, it is important to state that it is an indirect measurement since eluting non-oxidized FAME are quantified with addition of internal standard, and oxidized compounds are determined by difference. It is a measurement widely used to evaluate oxidation in general and has also been applied to microencapsulated CLA 
(Jiménez, García \& Beristain, 2004; Costa et al., 2015). With the purpose to evaluate the utility of substrate loss determination in the present study, selected samples of MT1 encapsulated oil fractions were analyzed. Results are shown in Table 4. While formation of polymerization compounds was consistent from the beginning of oxidation and increased significantly at 48 days (2\%), substrate loss measurement showed important fluctuations and only changed significantly after 64 days, when polymerization compounds were already $13.3 \%$. Furthermore, sample replicates showed relative standard deviations much higher for substrate loss determination than for polymer quantitation. Costa and coworkers have also reported very high standard deviations in oxidative stability studies of CLA microencapsulated in pea protein using substrate loss determination (Costa et al., 2015). These results are also in agreement with those previously obtained in our lab with model compounds of fatty acids methyl esters, which showed the low sensitivity of the substrate loss determination and the high variability of the values obtained (Márquez-Rui, Holgado, García-Martínez \& Dobarganes, 2007).

\section{Conclusions}

Polymerization in CLA-rich oil microencapsulated in skimmed milk components occurred since the beginning of the oxidation process and was markedly earlier and greater in the free oil fraction, hence showing the high protection provided by the encapsulation matrix. Oxidation of the encapsulated oil seemed to be unaffected by the removal of the free oil and subsequent drop of glass transition 
temperature thereby obtaining a functional ingredient of high oxidative stability. Also, results indicated the relevance of polymer formation and determination in microencapsulated CLA-rich oils and clearly showed the heterogeneity of oxidation in the encapsulated oil fraction. Further research is needed to gain insight into the oxidation events in microencapsulated CLA in order to guarantee protection of these bioactive but highly polymerizable fatty acids and preserve physical and chemical stability of functional foods containing them.

\section{Conflict of interest}

The authors declare no conflict of interest.

\section{References}

AOCS (1998) Method Cd 8-53. In: Firestone D (ed.), Official methods and recommended practices of the American Oil Chemists' Society (5th ed). Champaign: AOCS Press.

Bakry, A. M., Abbas, S., Ali, B., Majeed, H., Abouelwafa, M. Y., Mousa, A. \& Liang, L. (2016) Microencapsulation of Oils: A Comprehensive Review of Benefits, Techniques, and Applications. Comprehensive Reviews in Food Science and Food Safety, 15:143-182. https://doi.org/10.1111/1541-4337.12179

Brimberg, U.I., \& Kamal-Eldin, A. (2003) On the kinetics of the autoxidation of fats: Substrates with conjugated double bonds. European Journal of Lipid Science and Technology, 105:17-22. https://doi.org/10.1002/ejlt.200390000

Choi, K.-O, Ryu, J., Kwak H.-S. \& Ko, S. (2010) Spray-dried conjugated linoleic acid encapsulated with Maillard reaction products of whey proteins and maltodextrin. Food Science Biotechnology 19: 957-965. https://doi.org/10.1007/s10068-010-0134-7 
Costa, A.M.M., Nunes, J.C., Lima, B.N.B., Pedrosa, C., Calado, V., Torres, A.G., \& Pierucci, A.P.T.R. (2015) Effective stabilization of CLA by microencapsulation in pea protein. Food Chemistry, 168:157166.https://doi.org/10.1016/j.foodchem.2014.07.016

Dias, M.I., Ferreira, I.C.F.R., \& Barreiro, M.F. (2015) Microencapsulation of bioactives for food applications. Food \& Function, 6:1035-1052. https://doi.org/10.1039/C4FO01175A

Drusch, S. \& Mannino, S. (2009) Patent-based review on industrial approaches for the microencapsulation of oils rich in polyunsaturated fatty acids. Trends in Food Science \& 20:237-244. https://doi.org/10.1016/j.tifs.2009.03.007

Drusch, S., Serfert, Y., Scampicchio, M., Schmidt-Hansberg, B. \& Schwarz, K. (2007) Impact on physicochemical characteristics on the oxidative stability of fish oil microencapsulated by spray-drying. Journal of Agricultural and Food Chemistry, 55:11044-11051. https://doi.org/10.1021/jf072536a

Fritsche, J., Rickert, R., Steinhart, H., Yurawecz, M.P., Mossoba, M.M., \& Sehat, N. (1999) Conjugated linoleic acid (CLA) isomers: Formation, analysis, amounts in foods, and dietary intake. Fett-Lipid, 101:272-276.

https://doi.org/10.1002/(SICI)1521-4133(199908)101:8\%3C272::AID-

LIPI272\%3E3.0.CO;2-W.

García-Martínez, M.C., Márquez-Ruiz, G., Fontecha, J., \& Gordon, M.H. (2009) Volatile oxidation compounds in a conjugated linoleic acid-rich oil. Food Chemistry, 113: 926-931. https://doi.org/10.1016/j.foodchem.2008.08.020

García-Martínez, M.C., \& Márquez-Ruiz, G. (2009) Lipid Oxidation in Functional Dairy Products. Current Nutrition and Food Science, 5:209-216. https://doi.org/10.2174/157340109789007153

Ha, Y.L., Storkson, J., \& Pariza, M.W. (1990) Inhibition of benzo(a)pyreneinduced mouse forestomach neoplasia by conjugated dienoic derivatives of linoleic-acid. Cancer Research, 50:1097-1101.

Holgado, F., Márquez-Ruiz, G., Dobarganes, M.C., \& Velasco, J. (2013) Influence of homogenisation conditions and drying method on physicochemical properties of dehydrated emulsions containing different solid components. 
International Journal of Food Science and Technology, 48:1498-1508. https://doi.org/10.1111/ijfs.12118

IUPAC (1992) Method 2.301. Preparation of the fatty acid methyl esters. In: Standard methods for the analysis of oils, fats and derivatives (7th ed). Oxford: Pergamon.

IUPAC (1992) Method 2.302. Gas-liquid chromatography of fatty acid methyl esters. In: Standard methods for the analysis of oils, fats and derivatives (7th ed). Oxford: Pergamon.

IUPAC (1992) Method 2.508. Determination of polymerized triglycerides in oils and fats by high performance liquid chromatography. In: Standard methods for the analysis of oils, fats and derivatives (7th ed). Oxford: Pergamon.

IUPAC (1992) Method 2.432. Determination of tocopherols and tocotrienols in vegetable oils and fats by high performance liquid chromatography. In: Standard methods for the analysis of oils, fats and derivatives (7th ed). Oxford: Pergamon.

Jimenez, M., Garcia, H.S., \& Beristain, C.I. (2004) Spray-drying microencapsulation and oxidative stability of conjugated linoleic acid. European Food Research and Technology, 219:588-592.https://doi.org/10.1007/s00217004-0992-4

Jimenez, M., Garcia, H.S., \& Beristain, C.I. (2006) Spray-dried encapsulation of Conjugated Linoleic Acid (CLA) with polymeric matrices. Journal of the Science of Food and Agriculture, 86:2431-2437.https://doi.org/10.1002/jsfa.2636

Jimenez, M., Garcia, H.S., Beristain, C.I. (2010) Effect of water activity on physical properties of CLA (conjugated linolenic acid) microcapsules. Journal of Food Process Engineering, 33:434-447. https://doi.org/10.1111/j.17454530.2008.00283.x

Keogh, M. K., O'Kennedy, B. T., Kelly, J., Auty, M. A., Kelly, P. M., Fureby, A. \& Haahr, A.-M. (2001) Stability to oxidation of spray-dried fish oil powder microencapsulated using milk ingredients. Journal of Food Science, 66:217-224. https://doi.org/10.1111/j.1365-2621.2001.tb11320.x 
Kim, S.J., Park, G.B., Kang, C.B., Park, S.D., Jung, M.Y., Kim, J.O., \& Ha, Y.L. (2000) Improvement of oxidative stability of conjugated linoleic acid (CLA) by microencapsulation in cyclodextrins. Journal of Agricultural and Food Chemistry, 48:3922-3929.https://doi.org/10.1021/jf991215z

Lee, J.S., Song, Y.B., Lee, J.Y., Kim, M.K., Jun, S.J., \& Lee, H.G. (2009). Optimization and oxidative stability of the microencapsulated conjugated linoleic acid. International Journal of Biological Macromolecules, 45:348351.https://doi.org/10.1016/j.ijbiomac.2009.07.012

Luna, P., De La Fuente, M.A., Salvador, D., \& Márquez-Ruiz, G. (2007) Differences in oxidation kinetics between conjugated and non-conjugated methyl linoleate. Lipids, 42:1085-1092. https://doi.org/10.1007/s11745-007-3113-x

Malpuech-Brugere, C., Verboeket-van de Venne, W.P.H.G., Mensink, R.P., Arnal, M.A., Morio, B., Brandolini, M., Saebo, A., Lassel, T.S., Chardigny, J.M., Sebedio, J.L., \& Beaufrere, B. (2004) Effects of two conjugated linoleic acid isomers on body fat mass in overweight humans. Obesity Research, 12:591598.https://doi.org/10.1038/oby.2004.68

Márquez-Ruiz, G., Velasco, J., \& Dobarganes, M.C. (2003) Oxidation in dried microencapsulated oils. In: Kamal-Eldin, A. (Ed), Lipid Oxidation Pathways (pp.245-264). Champaign: AOCS Press.

Márquez-Ruiz, G., Holgado, F., García-Martínez, M.C., \& Dobarganes, M.C. (2007) A direct and fast method to monitor lipid oxidation progress in model fatty acid methyl esters by high-performance size-exclusion chromatography. Journal of Chromatography A, 1165:122-127. https://doi.org/ 10.1016/j.chroma.2007.08.001

Márquez-Ruiz, G., García-Martínez, M.C., Holgado, F., \& Velasco, J. (2014) Effectiveness of $\alpha-, \gamma$ - and $\delta$-tocopherol in a CLA-rich oil. Antioxidants, 3:176-188. https://doi.org/10.3390/antiox3010176

Márquez-Ruiz, G., Holgado, F., Ruiz-Méndez, M.V., Velasco, J., \& GarcíaMartínez, M.C. (2016) Oxidation of a functional, CLA-rich oil: determination of volatile and non-volatile compounds. European Food Research and Technology, 
242:1993-2000.

https://doi.org/10.1007/s00217-016-2698-9

Masso-Welch, P.A., Zangani, D., Ip, C., Vaughan, M.M., Shoemaker, S.F., McGee, S.O., \& Ip, M.M. (2004) Isomers of conjugated linoleic acid differ in their effects on angiogenesis and survival of mouse mammary adipose vasculature. Journal of Nutrition, 134: 299-307.https://doi.org/10.1093/jn/134.2.299

McNamee, B.F., O'Riordan, E.D., \& O'Sullivan, M. (1998) Emulsification and microencapsulation properties of gum arabic. Journal of Agricultural and Food Chemistry, 46:4551-4555. https://doi.org/10.1021/jf9803740

Morales, A., Marmesat, S., Ruiz-Méndez, M.V., Márquez-Ruiz, G., \& Velasco, J. (2015) New analytical evidence of discontinuous oxidation in dried microencapsulated lipids. Journal of the American Oil Chemists' Society, 92:1601-1607. https://doi.org/10.1007/s11746-015-2724-2

Pariza, M.W., Park, Y., \& Cook, M.E. (2000) Mechanisms of action of conjugated linoleic acid: Evidence and speculation. Proceedings of the Society for Experimental Biology and Medicine, 223:8-13. https://doi.org/10.1046/j.15251373.2000.22302.x

Richardson, G.H. (1985) Standard methods for the examination of dairy products $\left(15^{\text {th }}\right.$ ed) p.358. Washington DC:American Public Health Association.

Rodríguez-Alcalá, L.M., \& Fontecha, J. (2007) Hot topic: Fatty acid and conjugated linoleic acid (CLA) isomer composition of commercial CLA-fortified dairy products: Evaluation after processing and storage. Journal of Dairy Science, 90: 2083-2090. https://doi.org/10.3168/jds.2006-693

Saebo, A. (2003) Commercial synthesis of conjugated linoleate. In: Sebedio JL, Christie WW, Adlof R (Eds), Advances in CLA Research vol 2. (pp.71-81). Champaign: AOCS Press.

Sankarikutty, B., Sreekumar, M.M., Narayanan, C.S., \& Mathew, A.G. (1988) Studies on microencapsulation of cardamon oil by spray-drying technique. Journal of Food Science and Technology, 25:352-356. 
Shahidi, F., \& Han, X.Q. (1993) Encapsulation of food ingredients. Critical Reviews in Food Science and Nutrition, 33: 501547.https://doi.org/10.1080/10408399309527645

Thomas, M.E.C., Scher, J. \& Desobry-Banon, S. (2004) Milk powders ageing: effect on physical and functional properties. Critical Reviews in Food Science and Nutrition, 44:297-322. https://doi.org/10.1080/10408690490464041.

Velasco, J., Dobarganes, M.C., \& Márquez-Ruiz, G. (2000) Oxidation of free and encapsulated fractions in dried microencapsulated fish oils. Grasas $y$ Aceites, 51:439-456. https://doi.org/10.3989/gya.2000.v51. i6.463

Velasco, J., Marmesat, S., Dobarganes, M.C., \& Márquez-Ruiz, G. (2006) Heterogeneous aspects of lipid oxidation in dried microencapsulated oils. Journal of Agricultural Food Chemistry, 54:1722-1729. https://doi.org/10.1021/jf052313p

Velasco, J., Holgado, F., Dobarganes, M.C., \& Márquez-Ruiz, G. (2009) Influence of relative humidity on oxidation of the free and encapsulated oil fractions in freeze-dried microencapsulated oils. Food Research International, 42:1492-1500. https://doi.org/10.1016/j.foodres.2009.08.007

Whigham, L.D., Watras, A.C., \& Schoeller, D.A. (2007) Efficacy of conjugated linoleic acid for reducing fat mass: A meta-analysis in humans. American Journal of Clinical Nutrition, 85:1203-1211.

Yang, B., Chen, H., Stanton, C., Ross, R.P., Zhang, H., Chen, Y.Q., \& Chen, W. (2015) Review of the roles of conjugated linoleic acid in health and disease. Journal of Functional Foods, 15:314-325. https://doi.org/10.1016/j.jff.2015.03.050

Yurawecz, M.P., Delmonte, P., Vogel, T., \& Kramer, J.K.G. (2003) Oxidation of conjugated linoleic acid: Initiators and simultaneous reactions: Theory and Practice (pp 56-70). In Sebedio JL, Christie WW, Adlof R (Eds.) Advances in CLA Research, Vol. 2. Champaign: AOCS Press. 
Table 1.- Characterization of Tonalin $^{\mathrm{TM}}$ oil (TO)

TO

\begin{tabular}{|c|c|}
\hline \multicolumn{2}{|l|}{ Fatty acid composition (wt \%): } \\
\hline $16: 0$ & $2.4 \pm 0.0$ \\
\hline 18:0 & $2.6 \pm 0.1$ \\
\hline $18: 1$ & $14.2 \pm 0.2$ \\
\hline \multicolumn{2}{|l|}{$18: 29 c, 12 c$} \\
\hline $18: 29 c, 11 t$ & $39.2 \pm 0.5$ \\
\hline $18: 210 t, 12 c$ & $38.6 \pm 0.4$ \\
\hline Others & $3.0 \pm 0.0$ \\
\hline \multicolumn{2}{|l|}{ Tocopherols composition (mg/kg): } \\
\hline$\alpha$ & $81 \pm 4$ \\
\hline$\gamma$ & $416 \pm 10$ \\
\hline$\delta$ & $235 \pm 8$ \\
\hline Peroxide value (meq $\mathrm{O}_{2} / \mathbf{k g}$ ) & $2.5 \pm 0.2$ \\
\hline Dimers+ Polymers (wt \%) & $0.6 \pm 0.1$ \\
\hline Oxidative stability at $100^{\circ} \mathrm{C}(\mathrm{h})$ & $5.74 \pm 0.0$ \\
\hline
\end{tabular}

TO: Tonalin ${ }^{\mathrm{TM}}$ oil

Results are expressed as mean \pm standard deviation $(n=3)$. 
Table 2. - Physicochemical properties of microencapsulated TO samples (MT 1, MT 2 and MT 2b).

\begin{tabular}{|c|c|c|c|}
\hline & MT 1 & MT 2 & MT 2b \\
\hline \multicolumn{4}{|l|}{ Lipid distribution: } \\
\hline Total oil (g/100 g TM) & $8.12 \pm 0.50$ & $8.15 \pm 0.45$ & \\
\hline Free oil (g/100 g TM) & $0.97 \pm 0.03^{a}$ & $0.51 \pm 0.02^{b}$ & \\
\hline Encapsulation efficiency (\%) & $88.0 \pm 1.62^{a}$ & $93.7 \pm 1.30^{b}$ & \\
\hline \multicolumn{4}{|l|}{$\begin{array}{l}\text { Oil droplet size: } \\
\text { (lens } 45 \mathrm{~mm} \text { ) }\end{array}$} \\
\hline $\mathrm{d}_{(\mathrm{v}, 0.5)}(\mu \mathrm{m})$ & $0.62 \pm 0.01^{a}$ & $0.74 \pm 0.02^{b}$ & $0.70 \pm 0.05^{b}$ \\
\hline$d_{(v, 0.9)}-d_{(v, 0.1)}(\mu m)$ & $10.52 \pm 1.26^{a}$ & $9.31 \pm 0.87^{a}$ & $7.52 \pm 0.24^{b}$ \\
\hline $\mathrm{D}[3,2](\mu \mathrm{m})$ & $0.60 \pm 0.04$ & $0.58 \pm 0.05$ & $0.55 \pm 0.01$ \\
\hline $\mathrm{SA}\left(\mu \mathrm{m}^{-1}\right)$ & $10.00 \pm 0.14$ & $10.34 \pm 0.30$ & $10.91 \pm 0.15$ \\
\hline Water activity, $a_{w}$ & $0.20 \pm 0.00$ & $0.18 \pm 0.00$ & $0.20 \pm 0.00$ \\
\hline $\begin{array}{l}\text { Glass transition temperature, } \mathrm{Tg} \\
\left({ }^{\circ} \mathrm{C}\right)\end{array}$ & $63.9 \pm 0.5^{a}$ & $75.4 \pm 0.6^{b}$ & $32.3 \pm 0.8^{b}$ \\
\hline \multicolumn{4}{|l|}{ Colour parameters: } \\
\hline $\mathrm{L}^{*}(\mathrm{D} 65)$ & $94.06 \pm 0.14$ & $94.39 \pm 0.11$ & $94.41 \pm 0.07$ \\
\hline$a^{*}(D 65)$ & $-1.73 \pm 0.04^{a}$ & $-1.72 \pm 0.04^{a}$ & $-2.15 \pm 0.17^{b}$ \\
\hline$b^{\star}(D 65)$ & $11.99 \pm 0.14^{a}$ & $13.32 \pm 0.15^{b}$ & $12.60 \pm 0.14^{b}$ \\
\hline Solubility, t (s) & $260 \pm 1^{a}$ & $230 \pm 1^{b}$ & $245 \pm 1^{b}$ \\
\hline $\mathrm{pH}$ & $6.7 \pm 0.04$ & $6.7 \pm 0.05$ & $6.53 \pm 0.05$ \\
\hline
\end{tabular}

TO: Tonalin ${ }^{\mathrm{TM}}$ oil

MT: Microencapsulated Tonalin ${ }^{\mathrm{TM}}$ oil

SA: Surface area

Results are expressed as mean \pm standard deviation $(n=3)$.

Different letters in the same row indicate significant differences $(p<0.05)$. 
Table 3.- Characterization of extracted oils from initial microencapsulated TO samples (MT 1, MT 2 and MT 2b).

\begin{tabular}{|c|c|c|c|c|c|c|}
\hline & & \multicolumn{2}{|c|}{ MT 1} & \multicolumn{2}{|c|}{ MT 2} & \multirow{2}{*}{ MT 2b } \\
\hline & & Free & Encapsulated & Free & Encapsulated & \\
\hline \multicolumn{7}{|c|}{ Fatty acid composition (\%) } \\
\hline C16:0 & & $6.8 \pm 0.2$ & $6.6 \pm 0.2$ & $3.7 \pm 0.3$ & $3.0 \pm 0.2$ & $3.1 \pm 0.1$ \\
\hline C18:0 & & $5.2 \pm 0.2$ & $4.1 \pm 0.0$ & $3.3 \pm 0.2$ & $2.9 \pm 0.0$ & $3.0 \pm 0.1$ \\
\hline C18:1 & & $14.2 \pm 0.0$ & $15.2 \pm 0.1$ & $13.9 \pm 0.0$ & $14.4 \pm 0.1$ & $14.5 \pm 0.2$ \\
\hline \multirow{2}{*}{ C18:2 } & $(9 c, 11 t)$ & $33.8 \pm 0.6$ & $34.2 \pm 0.7$ & $38.4 \pm 0.6$ & $39.0 \pm 0.7$ & $38.7 \pm 0.5$ \\
\hline & $(10 t, 12 c)$ & $34.1 \pm 0.4$ & $34.2 \pm 0.5$ & $37.1 \pm 0.4$ & $37.7 \pm 0.5$ & $37.0 \pm 0.4$ \\
\hline Others & & $5.9 \pm 0.3$ & $5.8 \pm 0.4$ & $3.6 \pm 0.3$ & $3.1 \pm 0.2$ & $3.3 \pm 0.3$ \\
\hline \multicolumn{2}{|c|}{ Tocopherols (mg/kg) } & $502 \pm 15^{a}$ & $691 \pm 17^{b}$ & $683 \pm 20$ & $720 \pm 18$ & $652 \pm 15$ \\
\hline \multicolumn{2}{|c|}{ Dimers + Polymers (\%) } & $0.5 \pm 0.1$ & $0.2 \pm 0.1$ & $0.5 \pm 0.1$ & $0.2 \pm 0.1$ & $0.2 \pm 0.1$ \\
\hline
\end{tabular}

TO: Tonalin ${ }^{\mathrm{TM}}$ oil

MT: Microencapsulated Tonalin ${ }^{\mathrm{TM}}$ oil

Results are expressed as mean \pm standard deviation $(n=3)$.

Different letters in the same row indicate significant differences between values of free and encapsulated fractions $(p<0.05)$. 
Table 4. - Evolution of substrate loss and formation of polymerization compounds in encapsulated oil fraction of MT1 samples.

\begin{tabular}{ccccc}
\hline \multirow{2}{*}{ Days } & \multicolumn{2}{c}{ Substrate loss $(\%)$} & \multicolumn{2}{c}{ Dimers + Polymers (\%) } \\
\cline { 2 - 5 } & Mean & RSD $(\%)$ & Mean & RSD $(\%)$ \\
\hline 0 & 0.0 & 0.0 & 0.2 & 8.3 \\
4 & 1.1 & 62.0 & 0.2 & 9.4 \\
7 & 0.8 & 54.2 & 0.2 & 9.1 \\
14 & 3.2 & 47.2 & 0.5 & 8.5 \\
27 & 1.2 & 205.4 & 0.3 & 9.9 \\
35 & 0.4 & 32.1 & 0.6 & 6.2 \\
42 & 0.6 & 148.5 & 0.6 & 8.0 \\
48 & 4.3 & 33.5 & 2.0 & 18.7 \\
50 & 4.7 & 22.0 & 1.0 & 6.5 \\
55 & 3.8 & 29.5 & 2.7 & 7.0 \\
57 & 1.8 & 165.4 & 2.5 & 8.8 \\
62 & 3.9 & 59.3 & 5.0 & 7.2 \\
64 & 13.3 & 32.2 & 7.4 & 8.3 \\
69 & 13.5 & 10.4 & 7.6 & 4.2 \\
71 & 13.9 & 11.2 & 7.8 & 5.9 \\
77 & 13.7 & 9.8 & 8.9 & 3.9 \\
80 & 29.3 & 5.6 & 9.9 & 5.1 \\
\hline
\end{tabular}

MT: Microencapsulated Tonalin ${ }^{\mathrm{TM}}$ oil

Results are expressed as mean \pm relative standard deviation ( $n=3$ samples). 


\section{Legends for figures:}

Figure 1.- Oil globule size distribution and differential scanning calorimetry thermograms of microencapsulated Tonalin oil samples (MT1 and MT2) and microencapsulated Tonalin oil devoid of free oil fraction (MT2b).

Figure 2.- Time-course of formation of dimers and polymers $(D+P)$ (circle) and retention of tocopherols (triangle) in bulk Tonalin oil samples (TO), free and encapsulated (enc) oil fractions of microencapsulated Tonalin oil samples (MT1 and MT2) and in microencapsulated Tonalin oil devoid of free oil fraction (MT2b) during oxidation at $30^{\circ} \mathrm{C}$ in the dark. Values correspond to means of triplicate samples and error bars to standard deviations.

Figure 3.- Tocopherols (Toc) - to - dimers (D) and polymers $(P)$ ratios in free and encapsulated oil fractions of microencapsulated Tonalin oil samples MT1 (square) and MT2 (circle) oxidized at $30^{\circ} \mathrm{C}$ in the dark. 

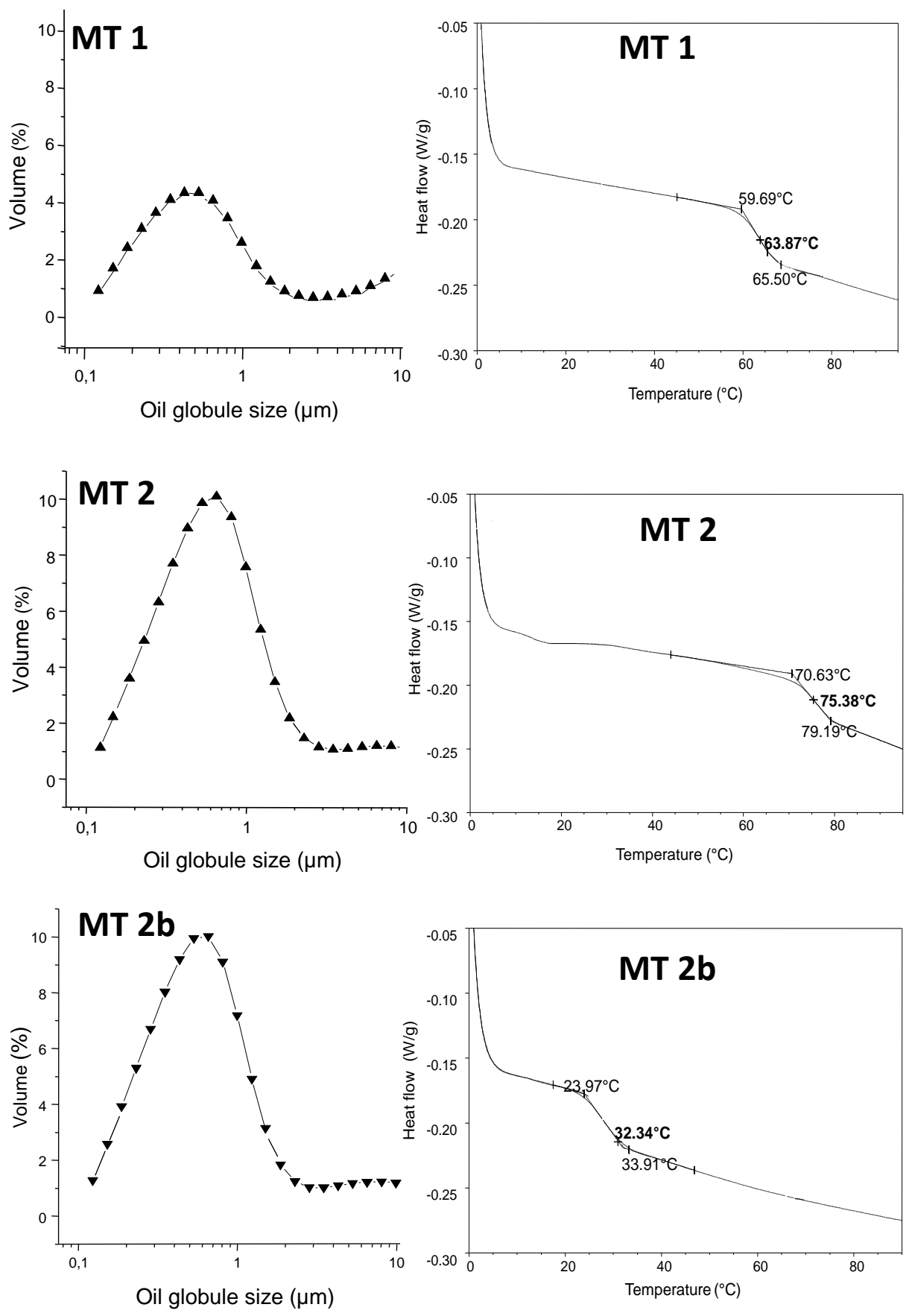

Figure 1 

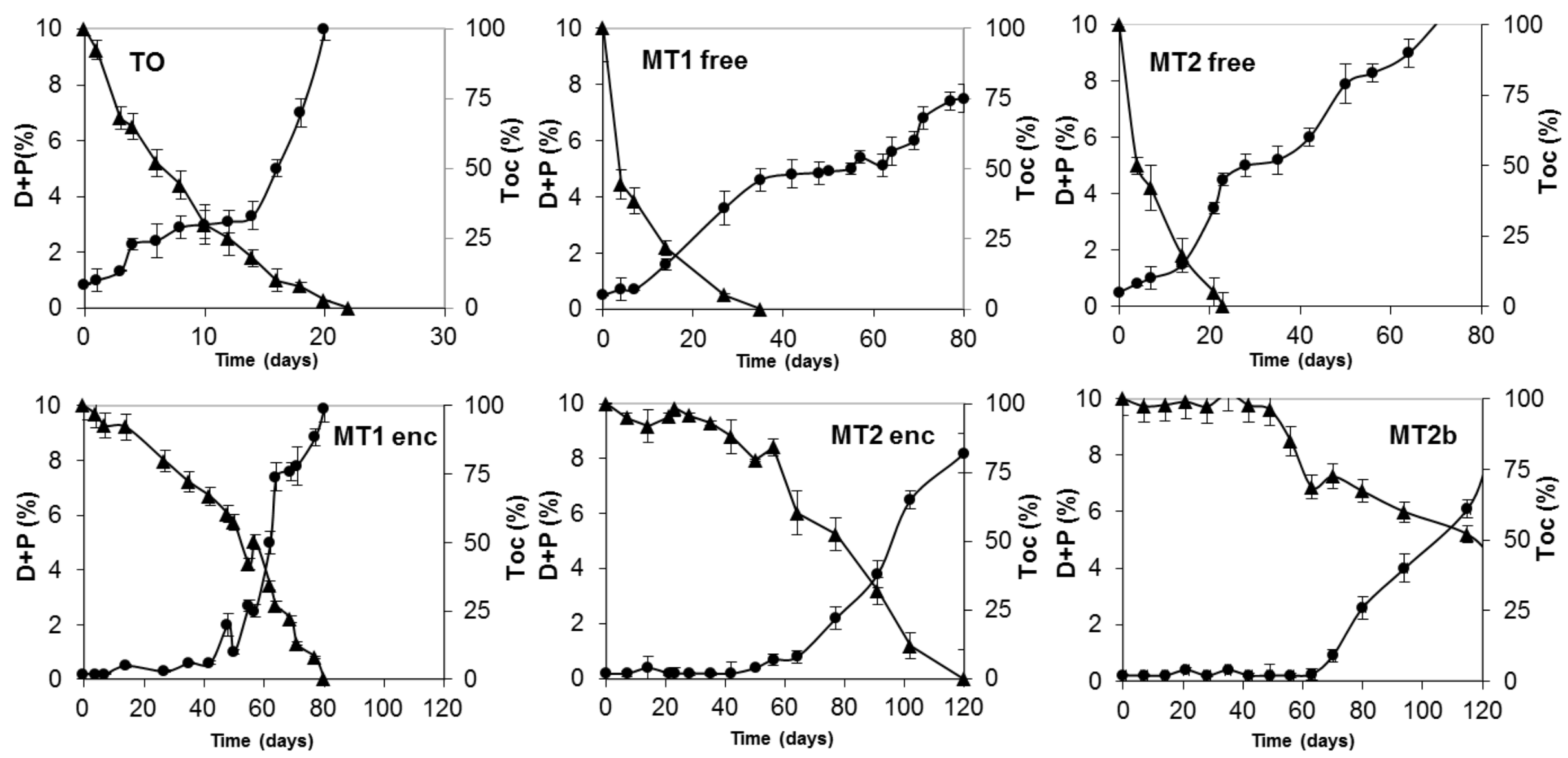

Figure 2 

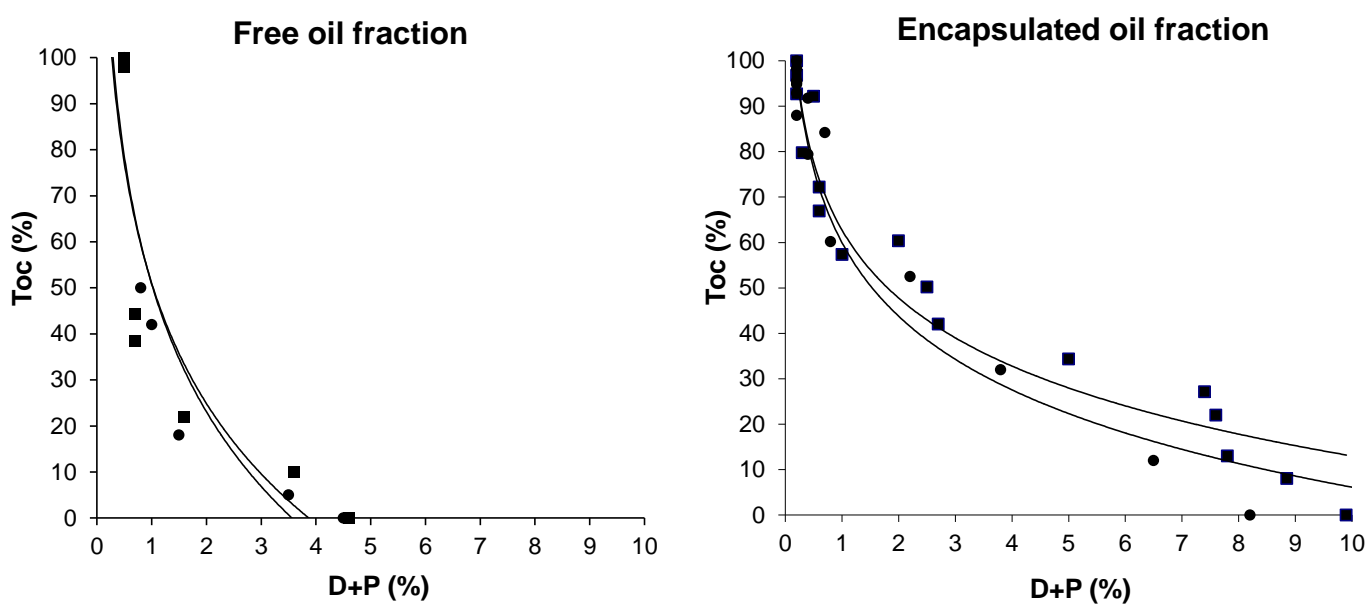

Figure 3 